\title{
Re-Imagining Machine Learning in Dental Research: A Lesson Learned from the COVID-19 Pandemic
}

Jafar Kolahi

Dental Hypotheses

Mohammad Seyedhamzeh

David G. Dunning

University of Nebraska Medical Center, ddunning@unmc.edu

Nader Kalbasi

Islamic Azad University

Tell us how you used this information in this short survey.

Follow this and additional works at: https://digitalcommons.unmc.edu/cod_articles

Part of the Dentistry Commons

\section{Recommended Citation}

Kolahi, Jafar; Seyedhamzeh, Mohammad; Dunning, David G.; and Kalbasi, Nader, "Re-Imagining Machine Learning in Dental Research: A Lesson Learned from the COVID-19 Pandemic" (2021). Journal Articles: College of Dentistry. 35.

https://digitalcommons.unmc.edu/cod_articles/35

This Article is brought to you for free and open access by the College of Dentistry at DigitalCommons@UNMC. It has been accepted for inclusion in Journal Articles: College of Dentistry by an authorized administrator of DigitalCommons@UNMC.For more information, please contact digitalcommons@unmc.edu. 

ERROR: undefined

OFFENDING COMMAND: get

STACK :

/ quit

-dictionary-

-mark- 